\title{
A comparison of the diet composition of two Sorex araneus populations under different heavy metal stress
}

\author{
Wim D. DENNEMAN
}

\begin{abstract}
Denneman W. D. 1990. A comparison of the diet composition of two Sorex araneus populations under different heavy metal stress. Acta theriol. 35: 25-38.

The food composition of two populations of the common shrew Sorex araneus Linnaeus, 1758 was studied. One population lived in the surrounding of a former zinc smelter in the Dutch province of Noord-Brabant, the other in the National Park "Hoge Veluwe". The whole contents of the alimentary tract of 112 specimens were analysed. The analysis was needed in a model study of the transfer of heavy metals in the food chain of this shrew. Qualitative and quantitative analyses both showed major prey types in all seasons were lumbricids, insect larvae (mainly Coleoptera and Lepidoptera), adult Coleoptera and Araneae. Opiliones only in autumn supplied a contribution to the diet. Soft prey animals contributed quantitatively for $40-50 \%$ to the total food intake. Significant differences in food choice between the two populations were noticed. This can be a factor of importance in transfer studies of toxic substances. Despite significant differences in heavy metal burden of the prey of contaminated and uncontaminated sites, both populations preferred Lumbricidae as a major prey. It is concluded that for both populations arthropod larvae increased in importance in the winter period, coleopteran larvae being the most important order. Throughout all seasons lumbricid earthworms are quantitatively the most important prey.
\end{abstract}

Institute for Environmental Studies, P. O. Box 7161, 1007 MC Amsterdam, The Netherlands

Key words: diet, Sorex araneus, food-chain, heavy metals

\section{Introduction}

During a study centred on the heavy metal transport in the terrestrial food-chain soil - invertebrates - Sorex araneus - Tyto alba, the diets of a Sorex araneus Linnaeus, 1758 population from polluted and unpolluted habitats were examined. The main purpose of the food analysis was to get information about the quantitative composition of the diet. Two different quantitative methods were used to analyse the alimentary tract contents, the results of which can be used to estimate heavy metal input in Sorex individuals by their diet. Data of accumulation and transport of heavy metals in the food-chain are published elsewhere (Denneman, in print).

In most previous studies on the diet of Sorex araneus, attemps at quantification of the diet were limited to calculation of the percentage frequency of occurrence of dietary items (Hamilton 1930, 1941, Mezhzherin 1958, Whittaker and Ferraro 1963, Buckner 1964, Rudge 1968, Yalden 1976, Grainger and Fairley 1978, Churchfield 1982). Only Pernetta (1976) recently evaluated a quantitative percentage dietary composition of the diets of the shrews Sorex araneus and Sorex minutus. In the present paper the quantification of the diet is also based on analysis of whole alimentary tracts instead of stomach contents alone, as used by most authors. 


\section{Methods \\ Study area}

The habitats under study were located in the Netherlands near Budel ( $\left.51^{\circ} 41^{\prime} 31^{\prime \prime} \mathrm{N}, 5^{\circ} 34^{\prime} 47^{\prime \prime} \mathrm{E}\right)$, near Arnhem ( $\left.50^{\circ} 01^{\prime} 02^{\prime \prime} \mathrm{N}, 5^{\circ} 52^{\prime} 54^{\prime \prime} \mathrm{E}\right)$ and Loenen ( $\left.52^{\circ} 05^{\circ} 00^{\prime \prime} \mathrm{N}, 5^{\circ} 55^{\circ} 00^{\prime \prime} \mathrm{E}\right)$. The sites near Budel have been contaminated with $\mathrm{Cd}, \mathrm{Zn}$ and $\mathrm{Pb}$ by former activities of nearby zinc smelters. At four sites in the immediate surrounding of the smelter shrews and invertebrates were sampled. The vegetation of the four sites (each of approximately 1 ha) is dominated by grasses (Agrostis capillaris, Holcus lanatus and Poa angustifolia). Young deciduous trees were planted, including the dominant species Quercus robur, Quercus rubra, and Betula pendula. At one site the tree layer is completely absent.

The uncontaminated Arnhem sites are situated amidst deciduous and coniferous woodland $(Q$. robur, Betula pendula and Pinus sylvestris) and are also approximately 1 ha in size. The herb layer is dominated by Vaccinium myrtillus. At all sites abundant ground cover was present at all times of the year.

\section{Sampling of soil and arthropods}

Samples of soil and litter were collected in early summer (May/June 1986), autumn (October 1986) and winter (February 1987). Soil samples were composed of 20 corings from a 50-m transect per trap line. All corings were $10 \mathrm{~cm}$ deep and were taken immediately under the litter layer, which was also sampled. The samples were dried $\left(75^{\circ} \mathrm{C}\right)$ and sifted through a $2-\mathrm{mm}$ mesh sieve before analysis.

Soil fauna were captured in the immediate surroundings of the traps $(<1.5 \mathrm{~m}$ of the traps) using pitfall traps filled with $80 \%$ alcohol. In the early summer period carres of soil $(25 \times 25 \mathrm{~cm})$ were sieved for underground larvae and less movable stages of the soil fauna. Earthworms (Lumbricus rubellus) were sampled by digging and hand-sorting of soil samples along the trap line. Adult worms were starved for three days on moist filter paper in Petri dishes to remove the gut contents prior to storage at $-20^{\circ} \mathrm{C}$.

Samples were dry-ashed in a low temperature plasma-ashing console (IPC) before analysis by flameless atomic absorption spectometry (AAS).

\section{Trapping method}

Shrews were caught using snap traps baited with bacon. Trap points were established at 5-meter intervals in trap lines of ten snap traps. At each site at least fifty traps were used. Working at all sites simultaneously shrews were trapped in early summer (21 May - 14 June 1986), autumn (13 - 31 October $1986)$ and winter (1 - 22 February 1987). The traps were visited twice a day, in the winter period often only once a day.

\section{Diet analysis}

The animals were stored at $-20^{\circ} \mathrm{C}$ until dissection was carried out. The whole alimentary tract was removed, divided into stomach (gullet included) and gut, weighed and stored in $80 \%$ alcohol at $20^{\circ} \mathrm{C}$. Prior to analysis the stomach and gut contents were dehydrated, then their weight recorded. The contents were rinsed with pure alcohol; debris was removed by washing twice with pure alcohol.

Micro-analysis of the whole contents of the separated stomach and gut was carried out on a random basis, using a petri dish with hundred squares. There were two stages of micro-analysis; firstly, qualitative analysis of the contents in alcohol, scoring the frequency of every item in the hundred carres at a homogeneous distribution of the contents. Secondly, different recognizable parts were identified following storage in lactic acid $(50 \%)$ for 2- 7 days. Sometimes Coomassie Brilliant Blue G-250 was used to recognize albuminous substances.

Soil fauna captured in the same area was mounted in polyester resin and Berleze's chloral gum (Williams 1962) and used as a reference collection. Also traditional whole animal key's were used. Acarina and nematods were mounted in slides with Berleze for analysis by specialized workers on these groups. 
Thirty three whole alimentary tracts from the early summer period were analysed to determine the amount of additional prey items in the intestine in comparison with that in the stomach. The linear regression (Fig. 1) shows that, when seven different prey items are found in the stomach, only rarely are one or more additional items found in the intestinal tract $(p<0.005)$. Assuming that the diversity of prey items is the highest in the early summer period, the remaining guts were only analysed when less then seven prey items occurred in the corresponding stomachs.

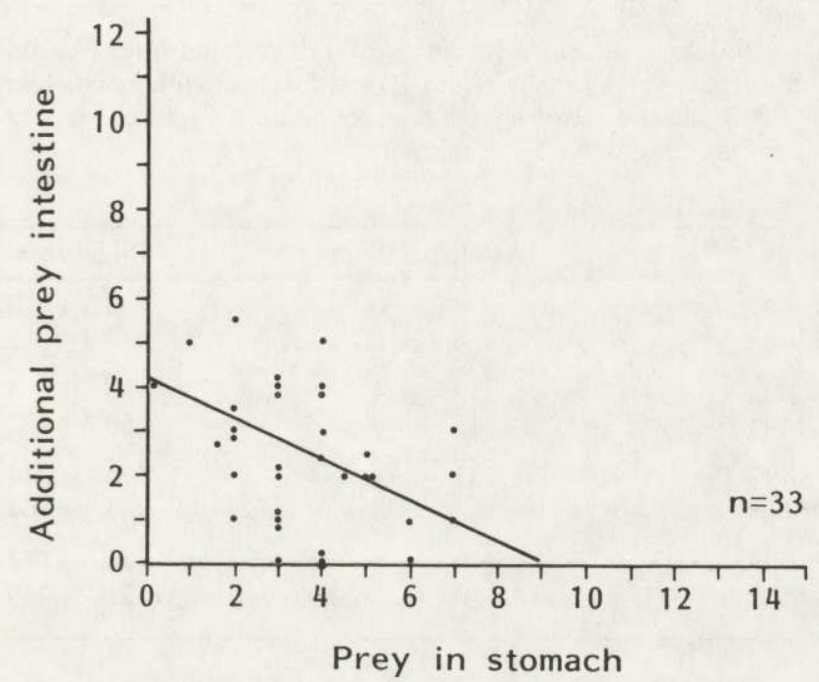

Fig. 1. The proportion of additional prey in the intestine in relation to the number of prey found in the stomach of individuals of $S$. araneus $(y=-0.492+4.25, p \leqslant 0.005)$.

\section{Quantitative diet analysis}

To compare the diet composition of the two populations, three methods for reproducing the results used; the (qualitative) frequency of occurrence and the (quantitative) mean surface covering and the (quantitative) percentage dietary composition.

The qualitative frequency of occurrence was calculated as the percentage of all whole intestinal tracts in a certain period that contained a prey item (Hamilton 1941, Yalden 1976, Grainger and Fairley 1978).

To quantify the proportion of every prey group (order), two methods were used. Firstly, the mean surface covering ( $M S C$ ) of every item within the hundred squares was recorded for each alimentary tract. To reduce errors due to an alimentary tract with contents that were almost totally digested, only contents with a minimum of $20 \%$ surface covering in the hundred squares petri dish were counted.

Secondly, from the different quantitative estimating methods of diet analysis the method of calculating the percentage dietary composition (PDC) was chosen (Pernetta 1976). The PDC was defined by the number of occurrences of a determined item, divided by the total number of occurrences of all items. According to McAtee (1912), Hynes (1950) and Yalden (1976):

$$
Z=\frac{A \times 100}{n \times \Sigma A_{\mathrm{i}} \mathrm{i}=1}
$$

taking into account that $A$ is the total number of food items of one prey species in all alimentary tracts and $n \times \Sigma A_{\mathrm{i}}$ is the total number of all identified food items in all alimentary tracts examined. 


\section{Results}

\section{Habitat characteristics}

Metal concentrations of soil and litter on both sites were significantly different (Table 1A). Despite large standard deviations especially at the four contaminated Budel sites, differences in $\mathrm{Cd}, \mathrm{Pb}$ and $\mathrm{Zn}$ existed in soil and litter. The $\mathrm{Cu}$ content of the soils was not different.

Table 1. Metal concentrations (mean $\pm \mathrm{SD}$ ) of soil and litter $(\mathrm{A})$ and plant species dominance (on a Tansley scale) $(\vec{B})$ at the Arnhem reference sites and the contamined Budel sites. Tansley scale of abundance: $1=$ rare, $2=$ occasional, $3=$ frequent, $4=$ abundant, $5=$ dominant.

\begin{tabular}{lcc}
\hline A. Metals and Sample & Arnhem $(\mathrm{n}=2)$ & Budel $(\mathrm{n}=4)$ \\
\hline Cd soil & $0.2 \pm 0.1$ & $3.3 \pm 0.9$ \\
Cd litter & $0.4 \pm 0.1$ & $7.3 \pm 2.7$ \\
Cu soil & $10 \pm 4$ & $18 \pm 5$ \\
Cu litter & $13 \pm 3$ & $50 \pm 22$ \\
Pb soil & $22 \pm 11$ & $120 \pm 44$ \\
Pb litter & $63 \pm 28$ & $263 \pm 164$ \\
Zn soil & $9 \pm 4$ & $348 \pm 113$ \\
Zn litter & $50 \pm 26$ & $1121 \pm 239$ \\
\hline
\end{tabular}

B. Vegetation layer

\begin{tabular}{lllll} 
Tree-layer & Quercus robur & 2 & Quercus robur & 3 \\
& Betula pendula & 3 & Betula pendula & 4 \\
& Pinus sylvestris & 5 & Pinus sylvestris & 1 \\
Herb-layer & Vaccinium myrtillus & 4 & Agrostis capillaris & 5 \\
& Deschampsia flexuosa & 5 & Holcus lanatus & 5 \\
& Hypnum cupressiforme & 3 & Poa angustifolia & 5 \\
& Carex arenaria & 2 & Rubus saxatilis & 3 \\
& & & Juncus effusus & 3 \\
& & & Lupinus luteus & 3 \\
\hline
\end{tabular}

The tree-layer was formed by the same species at both sites (Table 1B). At the Budel sites Pinus sylvestris was rare, whereas at the Arnhem sites this species was dominant. At all sites abundant ground cover was present at all times of the year. At the Budel sites, the number of plant species present in the field adds up to 46 . At the Arnhem sites, 15 plant species could be found.

Metal concentrations of the invertebrate fauna differed for $\mathrm{Zn}$ and $\mathrm{Cd}$ (Table 2). Copper concentrations were only different for Lepidoptera larvae. No differences in $\mathrm{Pb}$ concentrations were found. Araneae and Lumbricidae showed a strong accumulation of $\mathrm{Zn}$ and $\mathrm{Cd}$, compared with Lepidoptera and Coleoptera (larvae and adults). Biomass 
of Araneae and Coleoptera (larvae and adults) was higher at the Budel sites. On the other hand biomass of Opiliones at Budel was lower than at Arnhem.

\section{Qualitative diet analysis}

The diet of hundred and twelve individuals of $S$. araneus was analysed. The guts of eighty four animals $(75 \%)$ were examined in addition to their stomachs, because less than seven prey items were found (see also Fig. 1).

The maximum number of prey items identified in one stomach was 13 in autumn (Budel and Arnhem). No significant difference in the number of prey species occurring in the intestinal tract was found in the course of the year (annual mean Budel $7.7 \pm 1.15$, and Arnhem $6.9 \pm 1.0$ ).

The percentage frequency of occurrence of all groups $\geqslant 10 \%$ in the diet of $S$. araneus is shown in the Table 3. Major prey groups in all seasons are Arthropoda

Table 2. Metal concentrations (mean $\pm \mathrm{SD}$ ) of invertebrates and biomass (number of animals $\times \mathrm{ha}^{-1}$ ) captured in pitfall traps and analysed. Metal concentrations are the mean of two sites at Arnhem and four sites at Budel.

\begin{tabular}{lcccccccc}
\hline Metal and site & Araneae & $\begin{array}{c}\text { Coleoptera } \\
\text { larvae }\end{array}$ & $\begin{array}{c}\text { Lepidoptera } \\
\text { larvae }\end{array}$ & $\begin{array}{c}\text { Coleoptera } \\
\text { adult }\end{array}$ & Lumbricidae & Opiliones \\
\hline $\mathrm{Cd}$ & $51.8 \pm 17.1$ & $15.0 \pm 9.9$ & $2.9 \pm 1.5$ & $3.8 \pm 1.4$ & $82.1 \pm 36.3$ & $27.7 \pm 16.3$ \\
$\begin{array}{l}\text { Budel } \\
\text { Arnhem }\end{array}$ & $17.2 \pm 0.8$ & $2.5 \pm 0.5$ & $0.4 \pm 0.3$ & $1.3 \pm 0.3$ & $26.1 \pm 17.8$ & $5.4 \pm 1.2$ \\
$\mathrm{Cu}$ & $178 \pm 41$ & $68 \pm 28$ & $43 \pm 4$ & $32 \pm 6$ & $32 \pm 11$ & $70 \pm 8$ \\
$\begin{array}{l}\text { Budel } \\
\text { Arnhem }\end{array}$ & $216 \pm 32$ & $51 \pm 15$ & $14 \pm 5$ & $25 \pm 3$ & $29 \pm 26$ & $56 \pm 16$ \\
$\begin{array}{l}\text { Pb } \\
\text { Budel }\end{array}$ & $36 \pm 23$ & $21 \pm 14$ & $10 \pm 6$ & $19 \pm 9$ & $151 \pm 80$ & $22 \pm \pm 5$ \\
Arnhem & $11 \pm 3$ & $27 \pm 10$ & $5 \pm 6$ & $12 \pm 4$ & $71 \pm 17$ & $14 \pm 6$ \\
$\begin{array}{l}\text { Zn } \\
\text { Budel }\end{array}$ & $1624 \pm 261$ & $793 \pm 299$ & $600 \pm 180$ & $373 \pm 104$ & $2111 \pm 770$ & $1488 \pm 214$ \\
Arnhem & $800 \pm 107$ & $457 \pm 30$ & $371 \pm 356$ & $203 \pm 18$ & $492 \pm 164$ & $777 \pm 41$ \\
\hline $\begin{array}{l}\text { Biomass } \\
\text { Budel }\end{array}$ & 544 & 233 & 19 & 228 & 35 & 47 \\
$\begin{array}{l}\text { Biomass } \\
\text { Arnhem }\end{array}$ & 126 & 117 & 21 & 100 & 36 & 121 \\
\hline
\end{tabular}

larvae, in particular Coleoptera larvae and Lepidoptera larvae, adult Coleoptera (especially Carabidae, except in autumn), Araneae and Lumbricidae.

Lumbricidae (Oligochaeta) seem to be a very important prey during all seasons and in both areas (57-100\%, Table 3). Insect larvae and coleopteran larvae are also important although there is a difference in importance between the Budel and Arnhem habitats in autumn and winter. Carabidae formed the major part of coleopteran larvae found in Budel shrews in the autumn. Lepidoptera larvae occur at a frequency of about $50 \%$, except in the winter period when the frequency drops to $20 \%$. Adult 
Table 3. The frequency of occurrence of prey items in whole intestinal tracts of $S$. araneus in different seasons at the contaminated Budel $(n=4)$ and uncontaminated Arnhem sites $(n=2) .{ }^{*}$ Principally parasites without nutritive power.

\begin{tabular}{|c|c|c|c|c|c|c|}
\hline & \multicolumn{3}{|c|}{ Budel } & \multicolumn{3}{|c|}{ Arnhem } \\
\hline & Summer & Autumn & Winter & Summer & Autumn & Winter \\
\hline $\begin{array}{l}\text { Acarina, unident. } \\
\text { Oppia subpectinata } \\
\text { Oribatida } \mathrm{sp} \\
\text { Olodiscus minimus } \\
\text { Pergamasus } \mathrm{sp} \\
\text { Pterogastrina } \mathrm{sp}\end{array}$ & $\begin{array}{l}10 \\
5 \\
- \\
- \\
- \\
-\end{array}$ & $\begin{array}{l}35 \\
12 \\
12 \\
- \\
- \\
-\end{array}$ & $\begin{array}{l}- \\
\overline{-} \\
\overline{-} \\
\overline{-}\end{array}$ & $\begin{array}{l}9 \\
- \\
- \\
- \\
- \\
-\end{array}$ & $\begin{array}{l}40 \\
10 \\
- \\
10 \\
10 \\
10\end{array}$ & $\begin{array}{l}- \\
- \\
- \\
- \\
-\end{array}$ \\
\hline Araneae & 67 & 71 & 43 & 18 & 40 & 33 \\
\hline $\begin{array}{l}\text { Arthropoda larvae, total } \\
\text { Coleoptera larvae } \\
\text { Cantharidae larvae } \\
\text { Diptera larvae } \\
\text { Diptera, Nematocera larvae } \\
\text { Hemiptera larvae } \\
\text { Homoptera larvae } \\
\text { Lepidoptera larvae }\end{array}$ & $\begin{array}{l}90 \\
71 \\
14 \\
- \\
- \\
- \\
\overline{38}\end{array}$ & $\begin{array}{c}88 \\
65 \\
- \\
18 \\
6 \\
12 \\
- \\
53\end{array}$ & $\begin{array}{l}93 \\
79 \\
- \\
35 \\
21 \\
7 \\
14 \\
21\end{array}$ & $\begin{array}{l}82 \\
73 \\
- \\
- \\
- \\
- \\
\overline{55}\end{array}$ & $\begin{array}{l}70 \\
20 \\
- \\
- \\
- \\
- \\
\overline{60}\end{array}$ & $\begin{array}{l}55 \\
33 \\
- \\
20 \\
- \\
\overline{11} \\
22\end{array}$ \\
\hline Cestoda* & 5 & - & - & 27 & 10 & 12 \\
\hline $\begin{array}{c}\text { Coleoptera, total } \\
\text { Cantharidae } \\
\text { Carabidae } \\
\text { Curculionidae } \\
\text { Staphylinidae }\end{array}$ & $\begin{array}{l}71 \\
10 \\
48 \\
15 \\
14\end{array}$ & $\begin{array}{c}78 \\
- \\
24 \\
18 \\
6\end{array}$ & $\begin{array}{l}57 \\
- \\
43 \\
14 \\
-\end{array}$ & $\begin{array}{l}55 \\
- \\
18 \\
- \\
-\end{array}$ & $\begin{array}{l}40 \\
10 \\
30 \\
10\end{array}$ & $\begin{array}{l}44 \\
- \\
22 \\
22 \\
-\end{array}$ \\
\hline Dermaptera & - & - & 14 & - & - & - \\
\hline $\begin{array}{l}\text { Diptera, total } \\
\text { Diptera, eggs }\end{array}$ & $\begin{array}{l}24 \\
14\end{array}$ & $\begin{array}{c}18 \\
6\end{array}$ & $\begin{array}{l}21 \\
-\end{array}$ & $\begin{array}{l}18 \\
18\end{array}$ & $\begin{array}{l}10 \\
20\end{array}$ & - \\
\hline $\begin{array}{l}\text { Hymenoptera, total } \\
\text { Formicidae } \\
\text { Myrmicidae }\end{array}$ & $\begin{array}{l}33 \\
14 \\
14\end{array}$ & $\begin{array}{l}18 \\
6 \\
6\end{array}$ & $\begin{array}{l}7 \\
\overline{7}\end{array}$ & $\begin{array}{l}9 \\
\overline{9}\end{array}$ & $\overline{30}$ & $\begin{array}{l}11 \\
- \\
-\end{array}$ \\
\hline Oligochaeta: Lumbricidae & 81 & 88 & 57 & 91 & 100 & 56 \\
\hline Opiliones & - & 22 & 21 & - & 30 & 22 \\
\hline Nematoda* & 29 & 65 & 14 & 46 & 20 & 24 \\
\hline Number of samples & 23 & 17 & 24 & 20 & 19 & 9 \\
\hline
\end{tabular}

Frequency of occurrence $\leqslant 10 \%$ in all seasons:

Aves: Anseriformes / Acarina; Liebstadia similis, Galumna sp., Eulaelaps stabularis /Arthropoda eggs, indet. / Coleoptera: Carabidae larvae, Cryptofagus badius, Chrysomelidae, Hydrophylidae larvae Collembola sp. / Diptera: eggs of Muscidae, Nematocera, Sepsidae, Trichoceridae larvae / Enchytraeidae / Gastropoda: Basommatophora / Heteroptera / Hymenoptera larvae / Homoptera: Cicadina / Isopoda: Oniscidae/ Opiliones: Opilio parietinus / Siphonaptera sp.

coleopterans are of intermediate importance in the Arnhem habitats (40-50\%). This group seems to be more important in Budel since frequencies are higher (57-78\%). The major Coleoptera family that could be identified was Carabidae beetles.

Araneae were a major prey, especially in the Budel habitats while other groups occurred less frequently then $40 \%$. The frequency of occurrence of vegetable material 
$(71-100 \%)$ is not presented assuming that this item descended mainly from the intestinal tract of the prey. Also dicotyl seeds were found once in a stomach. Sand was also a very common item, which emphasises the importance of Lumbricidae earthworms.

Diptera eggs can form a food source of high nutritional value in early summer and autumn.

While Opiliones did not appear in the diet of Arnhem shrews in early summer and comprised less than $10 \%$ in Budel, this group gained importance in autumn and winter on both sites ( $30 \%$ and $22 \%$ resp. $22 \%$ and $21 \%)$.

\section{Quantitative diet analysis}

The mean covering percentage of dietary items with a coverage $\geqslant 1.0 \%$ are shown in Table 4. Lumbricids showed to be a constant part of the diet through all seasons and at all sites. Adult Coleoptera increased in importance in autumn and winter at all sites.

Table 4. Mean surface covering ( $M S C$ ) percentages of dietary items in early summer (ES), autumn (A) and winter (W). Remaining items not mentioned did have a coverage $<0.5 \%$ in all seasons. Only the stomach contents is taken into account, unlike Table 3 with the frequencies of occurrences of diet items.

\begin{tabular}{lccccccr}
\hline \multirow{2}{*}{ Item } & \multicolumn{3}{c}{ Budel } & & \multicolumn{3}{c}{ Arnhem } \\
\cline { 2 - 6 } & ES & A & W & & ES & A & W \\
\hline Oligochaeta: Lumbricidae & 19.8 & 16.9 & 19.8 & & 26.2 & 21.2 & 25.1 \\
Coleoptera adult without & & & & & & & \\
$\quad$ Carabidae & 2.9 & 1.1 & 10.5 & & $<1.0$ & 4.5 & 8.9 \\
Coleoptera: Carabidae & 1.0 & 3.5 & $<1.0$ & & 1.0 & $<1.0$ & $<1.0$ \\
$\quad$ Curculionidae & 0 & $<1.0$ & 1.0 & & 0 & 1.5 & 1.1 \\
Coleoptera, adult (total) & 4.2 & 7.6 & 11.6 & & $<1.0$ & 4.5 & 7.9 \\
Coleoptera larvae & 3.0 & 6.9 & 16.7 & & 4.3 & 0 & 12.2 \\
Diptera adult & $<1.0$ & 0 & 0 & & $<1.0$ & 0 & 0 \\
Diptera larvae & $<1.0$ & 2.6 & 6.9 & & 0 & 0 & 4.8 \\
Diptera: Nematocera larvae & $<1.0$ & 0 & 6.7 & & 0 & 0 & 1.0 \\
Araneida & 4.4 & 6.3 & 9.7 & & 5.4 & 2.9 & 10.4 \\
Opiliones & 0 & 3.1 & 1.0 & & 0 & 3.7 & $<1.0$ \\
Homoptera: Cicadina larvae & $<1.0$ & 0 & 1.0 & & 0 & 0 & 0 \\
Lepidoptera larvae & 8.8 & 1.8 & 3.3 & & 3.6 & 4.4 & 3.1 \\
Arthropoda larvae & 10.4 & 12.1 & 27.2 & & 8.8 & 4.4 & 15.9 \\
Arthropoda adult (total) & 15.8 & 17.4 & 23.1 & & 10.9 & 13.2 & 12.1 \\
\hline
\end{tabular}

This cannot be explained by a rise in prey numbers of Carabidae or Curculionidae (Table 3). Also the arachnids were found in larger proportions from summer to winter, while Opiliones supplied a contribution to the diet of the common shrew only in autumn.

On both sites Arthropoda larvae are of major importance in the winter period. This tendency is also seen in the consumption of Coleoptera and Diptera larvae. Only Lepidoptera larvae showed a relative constancy throughout the seasons, except in Budel during the early summer. 


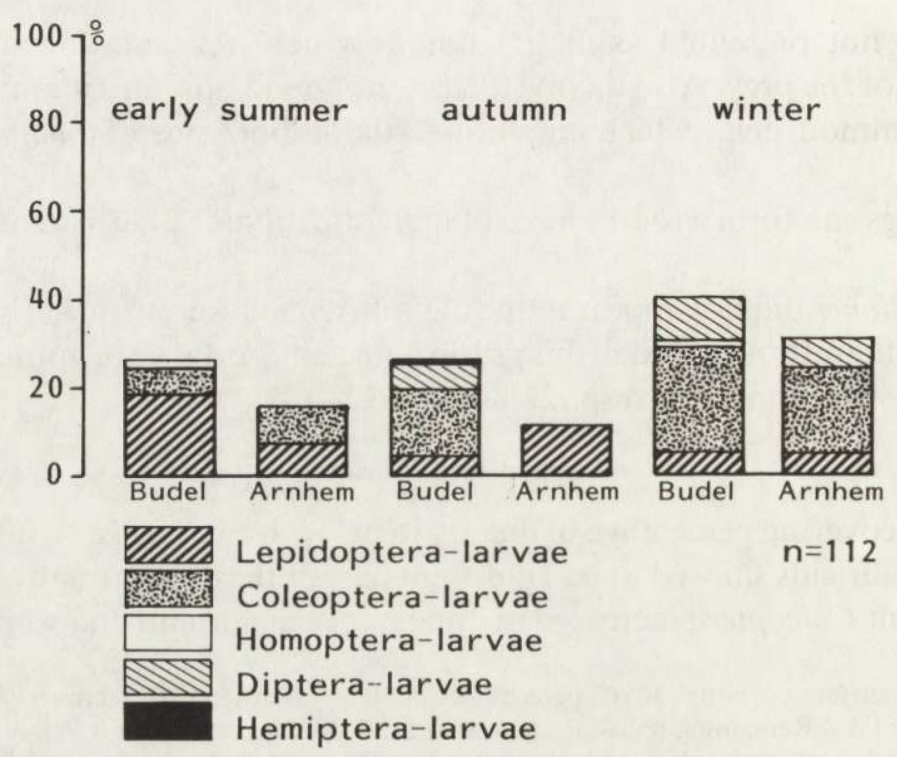

Fig. 2. Mean percentage dietary composition of the Arthropoda larvae in the stomachs of S. araneus from contaminated Budel $(n=64)$ and uncontaminated Arnhem $(n=48)$ sites. Only prey items $\geqslant 1 \%$ are subscribed.

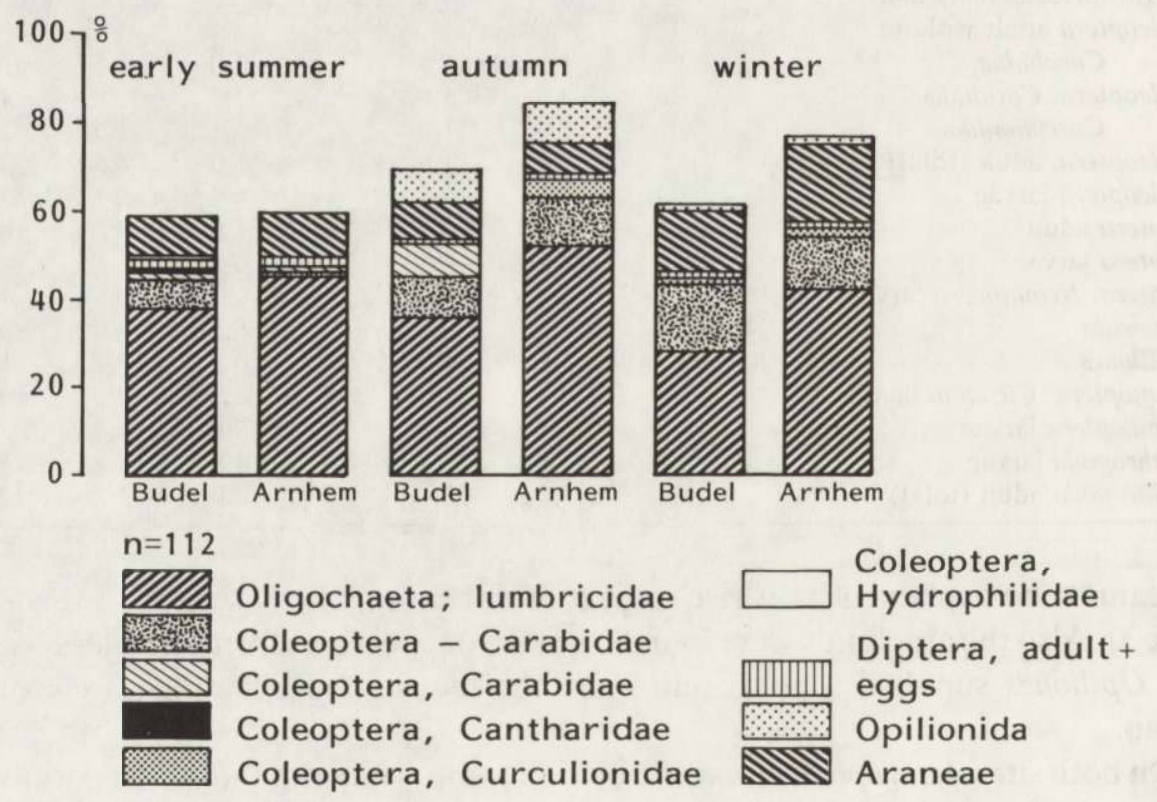

Fig. 3. Mean percentage dietary composition of the stomach contents of $S$. araneus from contaminated Budel $(n=64)$ and uncontaminated Arnhem $(n=48)$ sites. Only prey items $\geqslant 1 \%$ are subscribed, except Arthropoda larvae. 
The other quantitative method, the percentage dietary composition of the stomach contents, shows the same tendency for the consumption of larvae, only the resulting percentages differ. In Budel the total consumption of larvae increased from $27 \%$ in early summer and $26 \%$ in autumn to $39 \%$ in the winter period (Fig. 2). In Arnhem an increase from $15 \%$ and $11 \%$ to $31 \%$ respectively took place. In autumn and winter also the greatest diversity of larval orders appeared. Homoptera and Hemiptera larvae were present in a low percentage composition $(0.1-0.4 \%)$, while Nematocera larvae (Diptera) formed in Budel 9.5\% and in Arnhem $6.7 \%$ of the total composition in the winter.

Nematocera larvae generally live in pasture soils and in the litter layer of woods. Coleoptera larvae were the most important larval prey (in the winter $24 \%$ in Budel and $19 \%$ in Arnhem). Lepidoptera larvae showed the same trend through the seasons as in the mean surface covering, except in early summer in Budel (18\%). This last difference is mainly due to the presence of the pest species Operophtera brumata at some of the Budel sites in early summer. About $61 \%$ of the identified Lepidoptera larvae belonged to the Microlepidoptera, while the remaining part were Macrolepidoptera. The Lumbricidae earthworms are quantitatively the most important prey of $S$. araneus, even more important than insect larvae (Fig. 3). The frequent occurrence of sand in the stomachs also indicates the importance of earthworms in the diet. There is a significant difference $(p<0.01)$ in the percentages eaten in Arnhem and Budel; in both autumn and winter, up to $15 \%$ more earthworms were eaten by Arnhem shrews (Fig. 3, Table 4). The total consumption of adult arthropods was nearly always smaller than the amount of Lumbricidae eaten (Fig. 3). In Arnhem less adult Arthropoda were eaten than in Budel except in the winter period, when about $32 \%$ of the food were adult Arthropoda.

Table 5. Differences in food choise between the Budel and Arnhem population of $S$. araneus, based on the percentage dietary composition $(P D C)$. The observed values of any food item represent the $P D C$ of the Budel population. The expected values are represented by the PDC of the Arnhem population.

\begin{tabular}{|c|c|c|c|c|c|c|c|c|}
\hline \multirow{2}{*}{ Item } & \multicolumn{2}{|c|}{ Early summer } & \multicolumn{2}{|c|}{ Autumn } & \multicolumn{2}{|c|}{ Winter } & \multirow{2}{*}{$\chi^{2}$} & \multirow{2}{*}{$p$} \\
\hline & Obs. & Exp. & Obs. & Exp. & Obs. & Exp. & & \\
\hline $\begin{array}{l}\text { Arthropoda adult } \\
\text { larvae }\end{array}$ & $\begin{array}{l}26.3 \\
26.5\end{array}$ & $\begin{array}{l}17.8 \\
15.1\end{array}$ & $\begin{array}{l}38.8 \\
25.7\end{array}$ & $\begin{array}{l}29.4 \\
10.9\end{array}$ & $\begin{array}{l}32.9 \\
38.8\end{array}$ & $\begin{array}{l}31.1 \\
31.0\end{array}$ & $\begin{array}{r}7.2 \\
30.7\end{array}$ & $\begin{array}{l}0.01 \\
0.001\end{array}$ \\
\hline Lumbricidae & 38.2 & 45.1 & 36.0 & 52.3 & 28.2 & 42.0 & 10.7 & 0.01 \\
\hline Coleoptera: & 8.0 & 0.4 & 14.6 & 11.1 & 16.6 & 12.3 & 147 & 0.001 \\
\hline Carabidae & 2.0 & 1.0 & 7.4 & 0 & 0 & 0 & 55.8 & 0.001 \\
\hline \multicolumn{9}{|c|}{ Coleoptera: without } \\
\hline Carabidae & 6.1 & 0.2 & 8.6 & 11.1 & 14.9 & 12.0 & 170 & 0.001 \\
\hline Curculionidae & 0 & 0 & 0 & 3.7 & 1.1 & 1.5 & 7.3 & ns \\
\hline Coleoptera larvae & 5.7 & 8.2 & 14.6 & 0. & 23.9 & 18.7 & 215 & 0.001 \\
\hline Diptera eggs & 0.1 & 0.2 & 0.3 & 0.5 & 0 & 0.2 & 0.3 & ns \\
\hline larvae & 0 & 0 & 5.5 & 0 & 9.9 & 7.1 & 31.4 & 0.001 \\
\hline adult & 0.6 & 0.2 & 0 & 0 & 0.4 & 0 & 1.0 & ns \\
\hline Lepidoptera larvae & 18.0 & 6.7 & 3.6 & 10.9 & 4.7 & 4.2 & 24.0 & 0.001 \\
\hline Araneae & 9.2 & 9.4 & 7.8 & 7.2 & 13.9 & 16.7 & 0.5 & ns \\
\hline Opiliones & 0 & 0 & 6.5 & 9.1 & 1.2 & 0.7 & 1.1 & ns \\
\hline
\end{tabular}


Besides the different amounts of Lumbricidae and Arthropoda adults eaten by the two populations (Table 4), there was also a significant difference in the amount eaten of 7 other prey groups. While the Arnhem population consumed more Lumbricidae, the Budel population ate significantly more adult coleopterans (especially Carabidae), Lepidoptera larvae and Diptera larvae (Table 5). No significant differences in the consumption of Diptera (eggs and adults), Araneae, Opiliones and coleopteran Curculionidae were found.

The increasing importance of coleopterans in autumn and winter at both sites is striking. This group increased from $8 \%$ in early summer to $15 \%$ and $17 \%$ in autumn and winter in Budel and in Arnhem from $0.4 \%$ to $11 \%$ and $12 \%$ in the same periods.

It can be concluded that relatively soft prey animals (Lumbricidae and Arthropoda larvae) contributed quantitatively to $40-50 \%$ to the total food intake. The absence of a prey item in the quantitative analysis in spite of a high frequency of occurrence is an indication of its low energetic contribution to the diet. Diet items with a frequency of item in the quantitative analysis in spite of a high frequency occurrence $\leqslant 10 \%$ and which are quantitatively of no importance are summarized below Table 3 .

\section{Relationship with food availability}

Some calculations showed that there is little correlation between the diet of $S$. araneus and the seasonal numbers of its prey. For example, no significant correlation could be found between the mean dry weight per pitfall trap and the frequency of occurrence in the diet. Comparison of the density of prey expressed as dry weight per pitfall at each separated sample site and the frequency of occurrence showed an irregular pattern.

\section{Discussion}

\section{Diet examination and accuracy of methods}

As shrews ingest numerous easily fragmented invertebrates, a proper quantitative analysis of the diet is almost impossible. Direct counts tend especially to be misleading (Hansson 1970). The frequency of occurrence method, where the number of specimens containing a particular food item is given as a percentage of the total number of alimentary tracts analysed, only gives qualitative information. Even tiny amounts of an item have to be regarded as an observation and thus many frequencies approach relatively high percentages. The frequency of occurrence is not an appropriate measure to quantify the amount of a food item eaten by a predator. Its only relevance is to indicate the availability of or a preference for the food item. Nevertheless this method gives information about the stability of the prey choise of a population and has been widely used for the analysis of the food of shrews (Lavrov 1943, Mezhzherin 1958, Buckner 1964, Rudge 1968, Churchfield 1982).

The percentage dietary composition method, where each food item is expressed as a percentage of the total number of occurrences of all items, indicates more accurately 
the amount consumed of each prey. This method, in combination with the mean surface coverage, gives a more reasonable survey of prey items that could play a major role in the transfer of heavy metals to $S$. araneus (Denneman, in print). With all restrictions (Holišova 1966, Hansson 1970), these methods can be used to compare the two populations in their food choice.

A major point of criticism on the quantitative approach concerns the fact that particular prey items disintegrate more than others (e.g. Arthropoda). Lumbricidae earthworms were often reduced to a suspension of chaetae and fleshy parts. Mastication was least seen in Lepidoptera remains, so this group could be underestimated.

According to Pernetta (1976) the analysis of the whole alimentary tract seems to be the most adequate sample of the diet instead of stomach contents alone. The total weight of food contained in the alimentary tract (stomach and gut) represents approxiamately $5 \%$ of the daily intake, whereas the stomach contents alone represents only $1 \%$.

Assessment of the diet on the basis of stomach contents only would increase the inaccuracies of the results. In the present paper the frequencies of occurrence, mean surface covering and the $P D C$ are based on whole alimentary tracts and their full contents and not on a selection of the contents. Calculations to explain heavy metal accumulation in food-chains for example, will derive profit from the combination of these methods. Accuracy of the calculations will be improved compared with the results obtained by use of frequencies of occurrence, only since the combination leads to a minimum-maximum estimation.

\section{Diet composition and season}

The major prey types for both populations in all seasons were Lumbricidae, insect larvae (mainly Coleoptera and Lepidoptera), adult Coleoptera and Araneida.

The importance of Lumbricidae eartworms in the diet of $S$. araneus has frequently been reported (Evans 1948, Näsmark 1964, Raw 1966, Rudge 1968, Pernetta 1976, Funmilayo 1979), although there is no agreement about the importance in the winter diet. Pernetta (1976) assumed that Lumbricidae were more important in the winter months than in the summer. The present study found no evidence to support this assumption. Churchfield (1982) found Lumbricidae only of intermediate importance (based only on the frequency of occurrence), but this could also be due of the fact that she analysed faecal pellets. Butterfield et al. (1981) and Yalden (1981) called S. araneus a major lumbricid feeder and gave it as an example of prey distribution affecting predator distribution. Hawkins and Jewell (1962) showed a preference for Lumbricidae and maggots compared with mealworms (larvae of the beetle Tenebrio molitor) and one-day old mice.

Of seventeen authors who have published on the diet of $S$. araneus only Pernetta (1976) and Churchfield (1982) mentioned adult Coleoptera as a major prey throughout the year. Mezhzherin (1958) and Aitchinson (1987) mentioned Coleoptera as being 
mainly a winter prey. The results of the last authors agree with the results of this study, although there is a difference in the level of consumption of coleopterans in the Budel population (high) and the Arnhem population (intermediate).

Araneae were not eaten in different percentages throughout the year, which agrees with findings in England (Churchfield 1982) and Canada (Aitchinson 1987). Pernetta (1976) found that Araneae were a major prey only in the winter, Mezhzherin (1958) found an increase in the proportion Araneae eaten in the winter period.

Insect larvae were the fourth group which was quantitatively important, especially in the diet of the Budel population. Churchfield (1982) and Croin-Michielsen (1966) also called this group a major food item. Many authors found it to be of intermediate importance, often only based on frequencies of occurrence. Opiliones are mentioned by Churchfield (1982) and Pernetta (1976) as important food items, the latter also found a peak consumption in the autumn.

In the literature there is disagreement about the winter diet. Many authors claim that the common shrew is also carnivorous in the winter (Mezhzherin 1958, Kisielewska 1963, Pernetta 1976, Churchfield 1982), while others suggested that plant material is eaten in larger quantities in winter to supplement a lower number of invertebrates (Lavrov 1943, Kangur 1954, Zablotskaya 1957, Yudin 1962). In the present study the mean stomach and gut contents showed no significant changes in the different seasons, while most individuals in the winter period were caught under snow cover (February 1987). Fine vegetable material was assumed to descend from intestinal tracts of the prey. On one occasion a dicotyledon seed was found in a stomach. These two points do not support the view that shrews in Holland supplement their winter diet with vegetable material, even in severe winters.

The species composition of the prey also supports the view that $S$. araneus in Holland remains in the lower stratum of the soil during frost-free periods, while in autumn and winter the species becomes hypogean (Croin-Michielsen 1966).

\section{Diet composition and habitat characteristics}

Despite significant differences in food choice of the two populations (Table 5), both populations seem to prefer Lumbricidae as a major prey. Also, Araneae are frequently eaten. Both prey groups contained raised levels of $\mathrm{Cd}$ and $\mathrm{Zn}$ at the contaminated Budel sites. Differences in prey choice, however, seem to be more connected to differences in availability or preference, than to differences in heavy metal content. Biomass numbers showed greater availability of Araneae, Coleoptera larvae and Coleoptera adults for shrews moving around their home ranges at the Budel sites. In spite of this, Araneae were not significantly more eaten, at these sites. This is also observed for Opiliones, which were more abundant at the Arnhem sites.

Churchfield (1982) suggested that insect larvae seemed to be selected for, because they occurred in much larger proportions in the diet than in the invertebrate samples. Crowcroft (1957) mentioned that the common shrew has very pronounced likes and dislikes. Pierce (1987) showed in recently tested search path models of common shrews 
that they searched more efficiently than a random (neutral) model, and were approximately as efficient as the "optimal" model.

Pernetta (1976) too did not find a relationship between food availability in pitfall traps and diet in $S$. araneus. A possible explanation could be that this species relies less on prey active on the soil surface (Churchfield 1980, this study). However, it is also possible that in the runways of small mammals a specific invertebrate fauna exists, which is different from that caught by pitfall traps. Also clusters of prey animals (Kühnelt 1955, Cloudsley-Thompson 1958) can influence the dietary composition of $S$. araneus.

The present study indicates that realistic estimations of the input of toxic substances demand for an accurate food analysis in each concerned population. Generalizing of data shall lead to less accurate calculations.

Acknowledgements: I wish to thank D. van den Ham for his assistance in the field and Dr C. van den Bund and Dr A. Gilbert for their constructive criticism of early drafts of the manuscript. I am grateful to the National Forest Management SBB for permission to work at the Loenermark. The practical work of this study was carried out when the author was attached to the Research Institute for Nature Management, P. O. Box 9201,6800 HB Arnhem, The Netherlands.

\section{References}

Aitchinson C. W. 1987. Winter energy requirements of Soricine shrews. Mammal Rev. 17: 25-38.

Buckner C. H. 1964. Metabolism, food capacity and feeding behaviour in four species of shrews. Can. J. Zool. 42: 259-279.

Butterfield J., Coulson J. C. and Wanless S. 1981. Studies on the distribution, food, breeding biology and relative abundance of the pygmy and common shrews (Sorex mimutus and Sorex araneus) in upland areas of northern England. J. Zool., Lond. 195: 169-180.

Churchfield S. 1980. Population dynamics and the seasonal fluctuations in numbers of the common shrew in Britain. Acta theriol. 25: 415-424.

Churchfield J. S. 1982. Food availability and the diet of the common shrew Sorex araneus in Britain. J. Anim. Ecol. 51: 15-28.

Cloudsley-Thompson J. L. 1958. Spiders, Scorpions, Centipedes and Mites. The ecology and natural history of Woodlice, 'Myriapods' and Arachnids. Pergamom Press, London.

Croin-Michielsen N. 1966. Intraspecific and interspecific competition in the shrews Sorex araneus L. and $S$. minutus L. Arch. Néerl. Zool. 17: 73-174.

Crowcroft P. 1957. The life of the shrew. Reinhardt, London: 1-166.

Denneman W. D. (in print). Transport of heavy metals in the carnivorous food-chain of Sorex araneus and Tyto alba. Bull. Env. Contam. Toxicol.

Evans A. C. 1948. The identity of earthworms stored by moles. Proc. Zool. Soc. 118: 356-359.

Funmilayo O. 1979. Food consumption, preferences and storage in the mole. Acta theriol. 24: 379-389.

Grainger J. and Fairley J. S. 1978. Studies on the biology of the pygmy shrew Sorex minutus in the west of Ireland. J. Zool. 186: 109-141.

Hamilton W. J., Jr 1930. The food of the Soricidae. J. Mammal. 11: 26-39.

Hamilton W. J., Jr 1941. The food of small forest mammals in eastern United States. J. Mammal. 22: 250-263.

Hansson L. 1970. Methods of morphological diet micro-analysis on rodents. Oikos 21: 255-266. 
Hawkins A. E. and Jewell P. A. 1962. Food consumption and energy requirements of captive British shrews and the mole. Proc. Zool. Soc. Lond. 138: 137-155.

Holišova V. 1966. Food of an overcrowded population of the bank vole, Clethrionomys glareolus Schreb. in a lowland forest. Zool. Listy 15: 207-224.

Hynes H. B. N. 1950. The food of fresh-water sticklebacks (Gasterosteus aculeatus and Pygosteus pungitius) with a review of methods used in the studies of the food of fishes. J. Anim. Ecol. 19: 36-58.

Kangur R. 1954. Shrews as tree seed eaters in the Douglas fir region. Ore. St. Bd. for Salem. Res., note 17.

Kisielewska K. 1963. Food composition of Sorex araneus Linnaeus, 1758 in the light of parasitological research. Acta theriol. 7: 127-153.

Kühnelt W. 1955. A brief introduction to the major groups of soil animals. [In: Soil Zoology. D. Keith and E. M. Kevan, eds]. Butterworth Scientific Publications, London.

Lavrov N. F. 1943. On the biology of the common shrew (Sorex araneus L.). Zool. Zh. 22: 361-365.

McAtee W. L. 1912. Methods of estimating the contents of bird stomachs. Auk 29: 449-464.

Mezhzherin V. A. 1958. On feeding habitat of Sorex araneus L. and Sorex minutus L. Zool. Zh. 37: 948 - 953.

Näsmark O. 1964. Vinteraktivitet under snön hos land levande evertebrater. Zoologisk Revy 26: 5-15.

Pernetta J. C. 1976. Diets of the shrews Sorex araneus L. and Sorex minutus L. in Wytham Grassland . J. Anim Ecol. 45: 899-912.

Pierce G. J. 1987. Search paths of foraging common shrews Sorex araneus. Anim. Behav. 35: 1215-1224.

Raw F. 1966. The soil fauna as a food source for moles. J. Zool., Lond. 149: $50-54$.

Rudge M. R. 1968. The food of the common shrew Sorex araneus L (Insectivora: Soricidae) in Britain. J. Anim. Ecol. 37: 565-581.

Whittaker J. O., Jr and Ferraro M. G. 1963. Summer food of 220 short-tailed shrews from Ithaca, New York. J. Mammal. 44: 419.

Williams O. 1962. A technique for studying microtine food habits. J. Mammal. 43: 365-368.

Yalden D. W. 1976. The food of the hedgehog in England. Acta theriol. 21: 401-424.

Yalden D. 1981. The occurrence of the pygmy shrew Sorex minutus in moorland, and the implications for its presence in Ireland. J. Zool., Lond. 195: 147-156.

Yudin B. S. 1962. [Ecology of shrews (genus Sorex) in Western Siberia.]. Trudy Biol. Instituta Akad. Nauk SSSR, 8: 33 - 134. [In Russian]

Zablotskaya L. V. 1957. [Removal of coniferous and lime-tree seeds by shrews]. Trudy Prioksko-Terrasnogo Gos. Zapovednika 1: 242-247. [Cited in Yudin (1962)]. [In Russian]

Received 1 June 1989, accepted 6 August 1990. 